\title{
Hubungan Ketahanan Pangan dan Penyakit Diare dengan Stunting pada Balita 13-48 Bulan di Kelurahan Manyar Sabrangan, Surabaya
}

\section{Relations Food Security and Diarrheal Disease to Stunting in Under-Five Children Age 13-48 Months at Manyar Sabrangan, Mulyorejo Sub-District, Surabaya}

\author{
Chovinda Ayu Safitri*1, Triska Susila Nindya ${ }^{1}$
}

\begin{abstract}
ABSTRAK
Latar Belakang: Stunting merupakan keadaan kekurangan gizi akut yang menjadi salah satu penyebab kematian pada balita di dunia dan dapat berdampak pada kualitas kehidupan yang rendah di masa depan. Ketahanan pangan keluarga dan kejadian penyakit infeksi yang dialami balita terutama diare diindikasikan menjadi faktor yang dapat menyebabkan keadaan stunting. Balita usia 13-48 bulan merupakan kelompok yang rentan terhadap penyakit dan dampaknya. Keadaan stunting erat kaitannya dengan kerawanan pangan keluarga dan penyakit infeksi seperti diare yang dialami balita.

Tujuan: Untuk menganalisis hubungan ketahanan pangan keluarga dan penyakit diare dengan keadaan stunting balita.

Metode: Penelitian ini merupakan penelitian observasional analitik dengan rancang cross sectional. Sampel dalam penelitian ini adalah 68 balita usia 13-48 bulan di Kelurahan Manyar Sabrangan Kecamatan Mulyorejo Kota Surabaya. Pemilihan sampel menggunakan simple random sampling dengan teknik lotre. Pengambilan data dilakukan dengan metode wawancara dengan kuesioner. Ketahanan pangan diukur dengan menggunakan kuesioner United Stated-Household Food Security Survey Module (US-HFSSM). Analisis statistik dilakukan dengan menggunakan uji korelasi spearman $(\alpha=0,05)$.

Hasil: Hasil menunjukkan bahwa sebanyak 30,9\% balita mengalami stunting, 19,1\% mengalami diare, dan $61,8 \%$ berada pada keadaan rawan pangan. Ketahanan pangan keluarga dan keadaan stunting menunjukkan adanya hubungan yang signifikan $(p<0,05)$. Penyakit diare balita dan keadaan stunting tidak menunjukkan adanya hubungan yang signifikan $(p>0,05)$.

Kesimpulan: Dibutuhkan coping strategi dalam keluarga untuk mengatasi masalah kerawanan pangan yang terus-menerus. Terdapat faktor lain seperti riwayat asupan makanan yang dapat mempengaruhi stunting selain penyakit diare.
\end{abstract}

Kata kunci: stunting, ketahanan pangan, diare 


\begin{abstract}
Background: Stunting is an acute malnutrition that is one of the leading causes of death in under-five children in the world and can impact on low quality of life in the future. Household food security and infectious diseases especially diarrhea in under-five children are indicated to be factors that cause the stunting state. Toddlers 13-48 months old are likely have a high risk for disease and its effects. Stunting in under-five children is closely related to food insecurity of the family and diarrheal diseases by the children.

Objectives: The purpose of this study was to analyze the association of food security of the family and diarrheal diseases to stunting.

Methods: This research was an observational analytic with cross sectional design. The sample was 68 children under-five age 13-48 months in Manyar Sabrangan, Mulyorejo Sub-district, Surabaya. Selection of sample was using simple random sampling with lottery technique. The data were collected by interview method with questionnaire. Food security was accessed by US-HFSSM questionnaire. Spearman correlation test was used in the statistical analysis ( $\alpha=0.05)$.

Results: The data showed that the percentage of stunting, diarrhea, and household insecurity respectively $30.9 \%, 19.1 \%$, and $61.8 \%$. There was an association between food insecurity with stunting $(p<0.05)$. There was not an association between diarrhea with stunting ( $p>0.05)$.

Conclusions: It is necessary for family to have a coping strategy to avoid long-term food insecurity. There is another factor such as a history of food intake that may be able to affect stunting in addition to diarrhea.
\end{abstract}

Keywords: stunting, food security, diarrhea

\footnotetext{
*Koresponden:

chovinda@gmail.com

${ }^{1}$ Departemen Gizi Kesehatan, Fakultas

Kesehatan Masyarakat-Universitas Airlangga
} 


\section{PENDAHULUAN}

Malnutrisi merupakan suatu dampak keadaan status gizi baik dalam jangka waktu pendek maupun jangka waktu lama. Stunting merupakan salah satu keadaan malnutrisi yang berhubungan dengan ketidak cukupan zat gizi masa lalu sehingga termasuk dalam masalah gizi yang bersifat kronis ${ }^{1}$. Stunting merupakan ukuran status gizi balita dengan memperhatikan tinggi atau panjang badan, umur, dan jenis kelamin balita. Kebiasaan tidak mengukur tinggi atau panjang badan balita di masyarakat menyebabkan kejadian stunting sulit disadari. Hal tersebut membuat stunting menjadi salah satu fokus pada target perbaikan gizi di dunia sampai tahun $2025^{2}$.

Di dunia, 45 persen kematian pada balita disebabkan oleh keadaan malnutrisi yang beragam. Stunting merupakan salah satu keadaan malnutrisi yang berkontribusi secara signifikan dalam hal tersebut ${ }^{3}$. Dampak stunting pada balita dapat dilihat dalam jangka waktu pendek maupun panjang. Dampak yang ditemui dalam jangka pendek adalah balita lebih beresiko terkena penyakit infeksi yang mematikan, sedangkan dampak yang ditemui dalam jangka panjang adalah meningkatkan resiko penyakit kronis seperti kardiovaskular di masa depan².

Prevalensi stunting di Indonesia meningkat dari $35,6 \%$ di tahun 2010 menjadi $37,2 \%$ di tahun $2013^{4}$. Prevalensi tersebut masih jauh di atas target Rencana Pembangunan Jangka Menengah Nasional (RJPM) di tahun 2019 yaitu 28\% ${ }^{5}$. Hal tersebut menggambarkan bahwa stunting merupakan salah satu keadaan malnutrisi yang belum terselesaikan. Keadaan malnutrisi stunting pada balita dapat disebabkan oleh faktor langsung dan tidak langsung. Faktor langsung meliputi asupan makanan dan penyakit infeksi seperti diare. Faktor tidak langsung meliputi ketahanan pangan rumah tangga, pola asuh, dan keadaan lingkungan seperti higiene sanitasi, serta kondisi ekonomi keluarga balita ${ }^{6}$.

Pangan merupakan salah satu hal yang diperlukan manusia untuk bertahan hidup. Ketahanan pangan mengacu pada kemampuan individu atau kelompok dalam pemenuhan akses pangan yang cukup baik dari segi ekonomi maupun fisik, aman, dan bergizi untuk memenuhi kebutuhan agar dapat hidup dengan sehat dan baik ${ }^{7}$. Berbagai penelitian menunjukkan bahwa rumah tangga yang mengalami kerawanan pangan lebih cenderung memiliki balita dengan keadaan stunting $^{8}$. Keadaan balita seperti penyakit yang diderita juga menjadi salah satu faktor terjadinya stunting. Diare merupakan salah satu penyakit infeksi penyebab kematian pada balita di seluruh dunia pada situasi darurat. Balita pada rentang usia 13-48 bulan memliki prevalensi diare yang lebih tinggi daripada rentang usia lainnya ${ }^{4}$. Diare dapat disebabkan oleh faktor lingkungan seperti higiene sanitasi dalam keluarga. Perilaku higiene mencuci tangan merupakan salah satu cara untuk menghilangkan kuman dan bakteri penyebab diare $^{9}$. Sanitasi mengarah pada keadaan tempat tinggal dan fasilitas pembuangan urin serta feses dalam rumah tangga. Keadaan fasilitas sanitasi yang dimiliki tiap keluarga dapat memperngaruhi penyakit diare yang diderita anggota keluarga terutama pada balita $^{10}$.

Kelurahan Manyar Sabrangan Kota Surabaya merupakan salah satu kelurahan yang memiliki angka prevalensi stunting yang justru terus meningkat, yaitu $13,8 \%$ pada tahun 2014 dan 17,97\% pada tahun 2016. Hal tersebut menjadikan peneliti ingin mengetahui hubungan ketahanan pangan rumah tangga dan penyakit dengan kejadian stunting pada balita usia 13-48 bulan di Keluarahan Manyar Sabrangan Kota Surabaya.

\section{METODE}

Penelitian ini merupakan penelitian kuantitatif observasional analitik dengan menggunakan rancang bangun potong lintang (cross sectional). Penelitian ini dilakukan di Kelurahan Manyar Sabrangan Kota Surabaya, Provinsi Jawa Timur. Populasi dalam penelitian ini adalah balita dengan usia 13-48 bulan di Kelurahan Manyar Sabrangan Kota Surabaya. Sampel diambil secara acak sebanyak 68 balita dengan cara pengambilan sampel menggunakan teknik simple random sampling. 
Pengumpulan data primer meliputi umur serta jenis kelamin balita, pendapatan keluarga, higiene dan sanitasi, penyakit diare pada balita, ketahanan pangan rumah tangga, dan keadaan stunting pada balita. Kuesioner sanitasi menggunakan penilaian rumah sehat oleh Departemen Kesehatan RI (2007), ketahanan pangan US-HFSSM, dan pengukuran tinggi atau panjang badan balita menggunakan length board GEA dan mikrotoa One-Med dengan tingkat akurasi 0,1 sentimeter. Data yang terkumpul disajikan secara deskriptif menggunakan tabel frekuensi dan tabulasi silang. Analisis hubungan antar variabel dilakukan dengan menggunakan uji statistik korelasi Spearman dengan $\alpha=0,05$.

Penelitian ini telah mendapat persetujuan dari Komisi Etik Fakultas Kesehatan Masyarakat Universitas Airlangga Surabaya dengan nomor 168-KEPK tanggal 2 Mei 2017 serta Badan Kesatuan Bangsa dan Politik (Bakesbangpol) Kota Surabaya dengan nomor 170/4354/436.8.5/2017 tanggal 4 Mei 2017. Inform consent telah didapatkan dari masing-masing ibu/saudara/pengasuh balita.

\section{HASIL DAN PEMBAHASAN}

Distribusi frekuensi keadaan stunting, karakteristik balita dan keluarga, higiene sanitasi, kejadian diare, dan ketahanan pangan rumah tangga disajikan dalam (Tabel 1). Hasil menunjukkan bahwa $30,9 \%$ balita mengalami stunting. Presentase tersebut masih di atas target nasional yaitu sebesar $28 \%{ }^{11}$. Stunting merupakan gangguan pertumbuhan tinggi atau panjang badan. Peningkatan tinggi atau panjang badan pada balita lebih banyak dipengaruhi oleh pemberian kebutuhan pangan atau zat gizi dalam jangka waktu yang lama ${ }^{1}$. Balita yang tidak mendapatkan pangan atau zat gizi makro maupun mikro yang sesuai dengan kebutuhan secara terus menerus, maka pertumbuhan tinggi atau panjang badannya tidak normal atau pendek.

Kejadian diare pada balita menunjukkan bahwa hanya $19,1 \%$ balita mengalami diare. Penyakit diare pada balita umumnya disebabkan oleh virus seperti rotavirus dan calicivirus, serta bakteri seperti enteropathogenic Escherichia coli (EPEC) dan enterotoxigenic Escherichia coli (ETEC) yang kemudian masuk ke dalam tubuh dan mengganggu metabolisme dan kekebalan tubuh balita ${ }^{12}$. Faktor yang dapat mempengaruhi kejadian diare dapat berupa kebiasaan keluarga melakukan cuci tangan dengan sabun ${ }^{13}$. Hal tersebut membantu meminimalisasi persebaran bakteri patogen.

Hasil status ketahanan pangan keluarga menunjukkan bahwa 38,2\% keluarga berada pada status tahan pangan, namun jumlah presentase rawan pangan tanpa kelaparan hingga kelaparan berat juga tinggi yaitu sebesar $61,8 \%$. Kerawanan pangan keluarga tidak mendukung pertumbuhan, kesehatan, dan perkembangan kognitif ${ }^{14}$. Hal tersebut akan cenderung menimbulkan dampak malnutrisi untuk balita yang ada dalam keluarga ${ }^{15}$.

Uji statistik korelasi Spearman menunjukkan hasil bahwa ada hubungan antara higiene keluarga dengan kejadian diare pada balita. Keluarga yang memiliki kebiasaan mencuci tangan dengan menggunakan air tidak mengalir tanpa sabun sebagian besar memiliki balita yang terkena diare, sebaliknya bahwa keluarga yang memiliki kebiasaan mencuci tangan dengan menggunakan air mengalir dengan sabun sebagian besar memiliki balita yang tidak terkena diare (Tabel 2). Aktivitas sehari-hari dapat menyebabkan terkontaminasinya tangan dari banyak bakteri patogen dan menyebabkan beberapa penyakit infeksi tertentu. Kebiasaan mencuci tangan merupakan salah satu cara untuk mengurangi kejadian diare ${ }^{9}$. Mencuci tangan dengan menggunakan sabun membantu untuk lebih membersihkan bakteri patogen dan $48 \%$ dapat mengurangi resiko terjadinya diare ${ }^{16}$. Uji korelasi antara sanitasi rumah dengan kejadian diare pada balita juga menunjukkan adanya hubungan yang signifikan. Keluarga dengan sanitasi rumah memenuhi syarat sebagian besar memiliki balita yang tidak terkena diare, begitu pula sebaliknya. Hal tersebut terjadi karena sanitasi tidak memenuhi syarat, cenderung tidak memiliki penyediaan air bersih untuk mencuci tangan dan makanan maupun membersihkan peralatan makan sehingga kuman dan bakteri 
penyebab diare tidak dapat hilang. Penyediaan air berhubungan erat dengan kesehatan. Di negara berkembang, kekurangan penyediaan air yang baik sebagai sarana sanitasi akan meningkatkan terjadinya penyakit dan kemudian berujung pada keadaan malnutrisi ${ }^{17}$. Komponen fasilitas sanitasi yang tidak terpenuhi juga merupakan penyebab terjadinya diare dalam keluarga. Akses dan sarana toilet yang buruk, serta tidak adanya fasilitas pengelolaan tinja dan limbah akan menambah resiko terjadinya diare pada balita dalam keluarga karena persebaran virus, kuman, dan bakteri akan semakin tinggi ${ }^{18}$.

Tabel 1. Distribusi Karakteristik Balita, Pendapatan Keluarga, Kejadian Diare, Higiene dan Sanitasi, serta Ketahanan Pangan di Keluarahan Manyar Sabrangan, Surabaya.

\begin{tabular}{|c|c|c|}
\hline Variabel & $\mathbf{n}$ & $\%$ \\
\hline \multicolumn{3}{|l|}{ Stunting Balita } \\
\hline Ya & 21 & 30,9 \\
\hline Tidak & 47 & 69,1 \\
\hline \multicolumn{3}{|l|}{ Umur Balita (bulan) } \\
\hline $13-19$ & 10 & 14,7 \\
\hline $20-26$ & 13 & 19,1 \\
\hline $27-33$ & 13 & 19,1 \\
\hline $34-40$ & 12 & 17,7 \\
\hline $41-48$ & 20 & 29,4 \\
\hline \multicolumn{3}{|l|}{ Jenis Kelamin Balita } \\
\hline Laki-Laki & 36 & 52,9 \\
\hline Perempuan & 32 & 47,1 \\
\hline \multicolumn{3}{|l|}{ Pendapatan Keluarga } \\
\hline Kuintil 1 & 16 & 23,5 \\
\hline Kuintil 2 & 11 & 16,2 \\
\hline Kuintil 3 & 14 & 20,6 \\
\hline Kuintil 4 & 14 & 20,6 \\
\hline Kuintil 5 & 13 & 19,1 \\
\hline \multicolumn{3}{|l|}{ Diare Balita } \\
\hline Ya & 13 & 19,1 \\
\hline Tidak & 55 & 80,9 \\
\hline \multicolumn{3}{|l|}{ Higiene Cara Cuci Tangan } \\
\hline Air tidak mengalir tanpa sabun & 11 & 16,2 \\
\hline Air tidak mengalir dengan sabun & 12 & 17,6 \\
\hline Air mengalir tanpa sabun & 17 & 25,0 \\
\hline Air mengalir dengan sabun & 28 & 41,2 \\
\hline \multicolumn{3}{|l|}{ Sanitasi Rumah } \\
\hline Memenuhi Syarat & 47 & 69,1 \\
\hline Tidak Memenuhi Syarat & 21 & 30,9 \\
\hline \multicolumn{3}{|l|}{ Ketahanan Pangan } \\
\hline Tahan pangan & 26 & 38,2 \\
\hline Rawan pangan tanpa kelaparan & 18 & 26,5 \\
\hline Rawan pangan kelaparan ringan & 15 & 22,1 \\
\hline Rawan pangan kelaparan berat & 9 & 13,2 \\
\hline
\end{tabular}


Pada penelitian ini, hasil uji korelasi terhadap ketahanan pangan keluarga dengan kejadian stunting pada balita menunjukkan adanya hubungan yang signifikan $(p=0,01)$. Keluarga yang tahan pangan sebagian besar memiliki balita tidak stunting, sedangkan keluarga rawan pangan dengan kelaparan berat sebagian besar memiliki balita stunting (Tabel 3). Keadaan ketahanan pangan keluarga memiliki hubungan timbal balik dengan keadaan stunting pada balita (19). Status ketahanan pangan keluarga merupakan faktor krusial yang dapat mempengaruhi keadaan malnutrisi anggota keluarga terutama balita ${ }^{20}$. Penelitian di Bangladesh juga menunjukkan bahwa keadan rawan pangan kluarga berhubungan signifikan dengan kejadian stunting pada balita ${ }^{21}$. Keadaan rawan pangan dalam keluarga dapat meningkatkan resiko kegagalan partumbuhan ${ }^{22}$. Kerawanan pangan dalam keluarga dalam jangka waktu yang lama dapat mempengaruhi konsumsi makanan dengan cara mengurangi kuantitas maupun kualitas makanan kepada seluruh anggota keluarga terutama balita secara terus menerus, sehingga terjadi ketidak kecukupan zat gizi yang dibutuhkan oleh tubuh dan berdampak negatif pada pertumbuhan balita terutama tinggi badan ${ }^{23}$.
Hasil uji statistik korelasi antara penyakit diare dengan kejadian stunting pada balita menunjukkan tidak adanya hubungan yang signifikan $(p=0.190)$. Balita yang mengalami diare maupun tidak, sebagian besar sama-sama tidak mengalami masalah stunting (Tabel 2). Penelitian serupa di Peru, Brazil, Guinea-Bessau, dan Bangladesh menyebutkan bahwa penilaian panyakit diare kurang dari 30 hari tidak dapat menggambarkan hubungan yang signifikan terhadap pertumbuhan tinggi atau panjang badan balita ${ }^{24}$.

Stunting dapat dipengaruhi oleh banyak faktor terutama riwayat terdahulu dibandingkan dengan diare yang hanya dilihat dalam waktu yang singkat ${ }^{25}$. Faktor lain seperti keberagaman pangan baik zat gizi makro dan mikro terdahulu juga dapat mempengaruhi keadaan stunting pada balita ${ }^{26}$. Diare merupakan penyakit infeksi metabolisme yang dampaknya dapat langsung dilihat dalam jangka waktu yang singkat, sedangkan keadaan stunting merupakan malnutrisi yang bersifat kronis dampak dari keadaan yang terjadi dalam waktu yang lama dan terus-menerus. Hal tersebut membuat korelasi antar variabel tidak berhubungan.

Tabel 2. Hubungan Higiene dan Sanitasi dengan Diare pada Balita di Keluarahan Manyar Sabrangan, Surabaya.

\begin{tabular}{|c|c|c|c|c|c|c|c|}
\hline \multirow{3}{*}{ Variabel } & \multicolumn{4}{|c|}{ Diare } & \multirow{2}{*}{\multicolumn{2}{|c|}{ Total }} & \multirow{3}{*}{ P-value } \\
\hline & \multicolumn{2}{|c|}{ Ya } & \multicolumn{2}{|c|}{ Tidak } & & & \\
\hline & $\mathbf{n}$ & $\%$ & $\mathrm{n}$ & $\%$ & $n$ & $\%$ & \\
\hline \multicolumn{8}{|l|}{ Higiene Cara Cuci Tangan } \\
\hline Air tidak mengalir tanpa sabun & 8 & 72,7 & 3 & 27,3 & 11 & 100 & \\
\hline Air tidak mengalir dengan sabun & 5 & 41,7 & 7 & 58,3 & 12 & 100 & $<0,001$ \\
\hline Air mengalir tanpa sabun & 0 & 0,0 & 17 & 100,0 & 17 & 100 & \\
\hline Air mengalir dengan sabun & 0 & 0,0 & 28 & 100,0 & 28 & 100 & \\
\hline \multicolumn{8}{|l|}{ Sanitasi Rumah } \\
\hline Memenuhi syarat & 0 & 100,0 & 47 & 100,0 & 47 & 100 & $<0,001$ \\
\hline Tidak memenuhi syarat & 13 & 61,9 & 8 & 38,1 & 21 & 100 & \\
\hline
\end{tabular}


Tabel 3. Hubungan Ketahanan Pangan dan Diare dengan Stunting di Keluarahan Manyar Sabrangan, Surabaya.

\begin{tabular}{|c|c|c|c|c|c|c|c|}
\hline \multirow{3}{*}{ Variabel } & \multicolumn{4}{|c|}{ Stunting } & \multirow{2}{*}{\multicolumn{2}{|c|}{ Total }} & \multirow{3}{*}{ P-value } \\
\hline & \multicolumn{2}{|c|}{ Ya } & \multicolumn{2}{|c|}{ Tidak } & & & \\
\hline & $\mathbf{n}$ & $\%$ & $\mathbf{n}$ & $\%$ & $\mathbf{n}$ & $\%$ & \\
\hline \multicolumn{8}{|l|}{ Ketahanan Pangan } \\
\hline Tahan pangan & 3 & 11,5 & 23 & 88,5 & 26 & 100 & \\
\hline Rawan pangan tanpa kelaparan & 6 & 33,3 & 12 & 66,7 & 18 & 100 & 0,001 \\
\hline Rawan pangan kelaparan ringan & 5 & 33,3 & 10 & 66,7 & 15 & 100 & \\
\hline Rawan pangan kelaparan berat & 7 & 77,8 & 2 & 22,2 & 9 & 100 & \\
\hline \multicolumn{8}{|l|}{ Diare } \\
\hline Ya & 15 & 27,3 & 40 & 72,7 & 55 & 100 & 0,190 \\
\hline Tidak & 6 & 46,2 & 7 & 53,8 & 13 & 100 & \\
\hline
\end{tabular}

\section{KESIMPULAN}

Penelitian ini memberikan kesimpulan bahwa terdapat hubungan yang signifikan antara higiene dan sanitasi dengan penyakit diare pada balita usia 13-48 bulan. Ketahanan pangan berhubungan signifikan dengan kejadian stunting balita usia 13-48 bulan, sedangkan penyakit diare dan stunting tidak berhubungan secara signifikan. Perlu dilakukan penelitian serupa lebih lanjut dengan memperhatikan riwayat asupan makanan sebagai faktor lain yang dapat mempengaruhi kejadian stunting pada balita.

\section{ACKNOWLEDGEMENT}

Penghargaan diberikan penulis kepada seluruh staf pengajar program studi sarjana ilmu gizi Universitas Airlangga atas bimbingan dan dukungan yang telah diberikan.

\section{REFERENSI}

1. Gibson RS. Principles of Nutritional Assessment. New York: Oxford University Press 2005. p. 174-7.

2. Oot L, Sethuraman K, Ross J, Sommerfelt AE. The Effect of Chronic Malnutrition (Stunting) on Learning Ability, a Measure of Human Capital: A Model in PROFILES for Country-LevelAdvocacy. Food and Nutrition technical Assistance 2016: 3(1): 1-8. Available https://www.fantaproject.org/sites/de fault/files/resources/PROFILES-briefstuntinh-learning-Feb2016.pdf. Diakses pada 8 Juli 2017

3. Black RE, Victora CG, Walker SP, Bhutta ZA, Christian P, de-Onis $M$, Ezzati M, Grantham-McGregor S, Katz J, Martorell R, Uauy R. Maternal and Child Undernutrition and Overweight in Low-Income and Middle-Income Countries. The Lancet 2013; 382(9890): 427-51. Available from https://jhu.pure.elsevier.com/en/publi cations/maternal-and-child-

undernutrition-and-overweight-in-lowincome-an-3. Diakses pada 16 April 2017

4. Kementerian Kesehatan RI. Riset Kesehatan Dasar. 2013. Available from http://www.depkes.go.id/resources/d ownload/general/Hasil\%20Riskesdas\% 202013.pdf. Diakses pada 2 Oktober 2016.

5. Kementerian Perencanaan Pembangunan Nasional. Rencana Pembangunan Jangka Menengah Nasional 2015-2019. 2014. Available from

http://www.bpkp.go.id/public/upload/ unit/sesma/files/Buku\%20I\%20RPJMN \%202015-2019.pdf. Diakses pada 7 Juli 2017. 
6. The United Nations International Children's Emergency Fund. Improving Child Nutrition: The Achievable Imperative for Global Progress. Available from http://www.unicef.org/gambia/Impro ving_Child_Nutrition__the_achievable_imperative_for_glob al_progress.pdf. Diakses pada13 Juni 2017.

7. Food and Agriculture Organization. Food Security Information for Action Practical Guides: An Introduction to the Basic Concepts of Food Security. 2008. Available from http://www.fao.org/docrep/013/al936 e/al936e00.pdf. Diakses pada 19 Juni 2017.

8. Utami NH, Sisca D. Ketahanan Pangan Rumah Tangga Berhubungan dengan Status Gizi Anak Usia di Bawah Dua Tahun (Baduta) di Kelurahan Kebon Kelapa, Kecamatan Bogor Tengah, Jawa Barat, Journal of The Indonesian Nutrition Association 2015; 38(2): 10514.

9. Nwadiaro ERI, Ehiri JE, Arikpo D, Meremikwu MM, Crithley JA. Hand Washing Promotion for Preventing Diarrhoea (Review). Cochrane Library 2015; 1(9): 1-95. Available from https://www.ncbi.nlm.nih.gov/pmc/ar ticles/PMC4563982/pdf/CD0042650001.pdf. Diakses pada 10 Mei 2017.

10. Baker KK, O'Reilly CE, Levine MM, Kotloff KL, Nataro JP, Ayers TL, Farag $\mathrm{TH}$, Nasrin D, Blackwelder WC, Wu Y, Alonso PL, Breiman RF, Omore R, Faruque ASG, Das SK, Ahmed S, Saha $D$, Sow SO, Sur D, Zaidi AKM, Quadri F, Mintz ED. Sanitation and HygieneSpecific Risk Factors for Moderate-toSevere Diarrhea in Young Children in the Global Enteric Multicenter Study, 2007-2011: Case Control Study. PLOS Medicine 2016; 10(1371): 1-19. Available from http://journals.plos.org/plosmedicine/ article/file?id=10.1371/journal.pmed.1 002010\&type $=$ printable. Dlakses pada 17 Mei 2017.

11. Kementerian

Perencanaan

Pembangunan Nasional. Rencana Pembangunan Jangka Menengah Nasional 2015-2019. Available from http://www.bpkp.go.id/public/upload/ unit/sesma/files/Buku\%20I\%20RPJMN \%202015-2019.pdf. Diakses pada 7 Juli 2017.

12. Lanata $\mathrm{CF}, \quad$ Fischer-Walker $\mathrm{CL}$, Olascoaga AC, Torres CX, Aryee MJ, Black RE. Global Causes of Diarheal Disease Mortality in Children $<5$ Years of Age: A Systematic Review. PLOS ONE Journal 2013; 8(9): 1-11. Available from

http://journals.plos.org/plosone/articl e/file?id=10.1371/journal. pone.00727 88\&type=printable. Diakses pada 24 Juli 2017.

13. George CM, Perin J, Neisuender-deCalani KJ, Norman WR, Perry H, DavisJr TP, Lindquist ED. Risk Factors for Diarrhea in Children under Five Years of Age Residing in Peri-Urban Communities in Cochabamba, Bolivia. The American Society of Tropical Medicine and Hygiene 2014; 91(6): 1190-6. Available from https://www.ncbi.nlm.nih.gov/pmc/ar ticles/PMC4257646/pdf/tropmed-911190.pdf. Diakses pada 5 Juli 2017.

14. Cook JT, Frank DA. Food Security. Poverty, and Human Development in United States. Annals of the New York Academy of Sciences 2008; 10(1136): 193-209. Available from https://www.ncbi.nlm.nih.gov/pubme d/17954670. Diakses pada 2 Mei 2017.

15. Ajao KO, Ojofeitimi EO, Adebayo AA, Fatusi AO, Afolabi OT. Influence of Family Size, Household Food Security Status, and Child Care Practices on The Nutritional Status of Under-Five 
Children in Ile-Ife, Nigeria, African Journal of Reproductive Health 2010; 14(4): 123-32. Available from http://www.bioline.org.br/pdf?rh1007

2. Diakses pada 8 Juli 2017.

16. Cairncross S, Hunt C, Boisson S, Bosteon K, Curtis V, Fung ICH, Schmidt W. Water, Sanitation and Hygiene for the Prevention of Diarrhoea. International Journal of Epidemiology. 2010; 39:193-205. Available from https://www.ncbi.nlm.nih.gov/pmc/ar ticles/PMC2845874/pdf/dyq035.pdf. Diakses pada 12 Mei 2017.

17. Hunter PR, MacDonal AM, Carter RC. Water Supply and Health. PLOS Medicine 2010; 7(11): 1-9. Available from

http://journals.plos.org/plosmedicine/ article/file?id=10.1371/journal.pmed. 1 000361\&type $=$ printable. Diakses pada 8 Juli 2017.

18. Kyereme AK, Adjei JA. Household Wealth, Residential Status and The Incidence of Diarrhoea Among Children Under-Five Years in Ghana. Journal of Epidemiology and Global Health 2015; 6: 131-40. Available from http://www.sciencedirect.com/science /article/pii/S2210600615000581\#. Diakses pada 23 April 2017.

19. Hackett $M$, Melgar-Quiñonez $H$, Álvarez MC. Household Food Insecurity Associated with Stunting and Underweight among Pre-School Children in Antioquia, Colombia. Rev Panam Salud Publica 2009; 25(6): 50610. Available from http://www.scielosp.org/pdf/rpsp/v25 n6/v25n6a06.pdf. Diakses pada 10 Juli 2017.

20. Kandeepan K, Balakumar S, Arasaratnam V. Nutritional Status and Food Insecurity Among the Children in Northern Sri Lanka. Procedia Food Sciece 2015; Vol. 6: 220-24. Available from http://www.sciencedirect.com/science /article/pii/S2211601X16000171.

Diakses pada 30 April 2017.

21. Saha KK, Frongiillo EA, Alam DS, Arifeen SE, Persson LA, Rasmussen KM. Household Food Security is Associated with Growth of Infants and Young Children in Rural Bangladesh. Public Health Nutrition 2009; 12(9): 1556-62. Available from https://www.cambridge.org/core/serv ices/aop-cambridge-

core/content/view/326F13F7BAA48D9 0256F166296C033EC/S136898000900 4765a.pdf/household_food_security_i s_associated_with_growth_of_infants _and_young_children_in_rural_bangla desh.pdf. Diakses pada 9 Juli 2017.

22. Rose-Jacobs R, Black MM, Casey PH, Cook JT, Cutts DB, Chilton $M$, Heeren $T$, Levennsin SM, Meyers AF, Frank DA. Household Food Insecurity: Associations with At-Risk Infant and Toodler Development. Journal of Pediatrics 2008. 121(1): 65-72. Available from http://pediatrics.aappublications.org/c ontent/121/1/65.full-text.pdf. Diakses pada 17 Mei 2017.

23. Chaparro, C. Household Food Insecurity and Nutritional Status of Women of Reproductive Age and Children under 5 Years of Age in Five Departments of the Western Highlands of Guatemala: An Analysis of Data from the National MaternalInfant Health Survey 2008-09 of Guatemala. 2012. Washington, DC: FHI 360/FANTA-2 Bridge. Available from http://pdf.usaid.gov/pdf_docs/PAOOH PCN.pdf. Diakses pada 18 Mei 2017.

24. Richard SA, Black RE, Gilman RH, Guerrant RL, Kang $G$, Lanata $C F$, Mølbak K, Rasmussen ZA, Sack RB, Valentinor-Branth P, Checkley W. Diarrhea in Early Childhood: Short Term Association with Weight and 
Long-term Association with Length. American Journal of Epidmology 2013; 178 (7): 1129-38. Available from https://www.ncbi.nlm.nih.gov/pmc/ar ticles/PMC3783094/pdf/kwt094.pdf. Diakses pada 10 Juli 2017.

25. Walker CLF, Lamberti L, Adair L, Guerrant RL, Lescano AG, Martorell R, Pinkerton RC, Black RE. Does Childhood Diarrhea Influence Cognition Beyond the DiarrheaStunting Pathway?. PLOS ONE Journal 2012; 7(10): 1-6. Available from http://journals.plos.org/plosone/articl e/file?id=10.1371/journal. pone.00479 08\&type $=$ printable. Diakses pada 30 Juni 2017.
26. Rah JH, Akhter N, Semba RO, de-Pee $S$, Bloem MW, Campbell AA, MuenchPfanner R, Sun K, Badham J, Kraemer. Low Dietary Diversity is a Predictor of Child Stunting in Rural Bangladesh. European Journal of Chlinical Nutrition 2010; 64: 1393-8. Available from https://www.nature.com/ejcn/journal /v64/n12/pdf/ejcn2010171a.pdf.

Diakses pada 10 Juli 2017. 